\title{
Environmentally-friendly practices in hotels
}

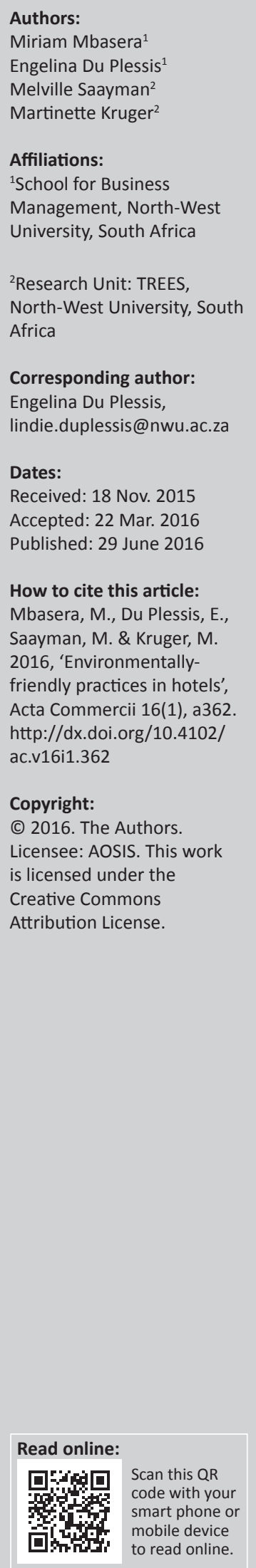

Orientation: There has been a growing concern for a 'green' hotel in the view of customers as they experience an increased awareness of environmental damage and excessive consumption of goods, energy and water.

Research purpose: To determine the environmentally-friendly practices in hotels in Zimbabwe and South Africa and establish the contribution that hotels are making towards mitigation of the negative environmental effects.

Motivation for the study: Currently, the world is facing environmental issues, which include global climate change, ozone depletion, pollution, high consumption of resources and increasing amounts of solid waste. Hotels, as part of the tourism industry, exert a significant impact on the environment. While the extent and range of the impact that hotels exert on the environment suggest an urgent need to address this problem, the question that arises is whether hoteliers appreciate the need for environmentally-friendly initiatives in their establishments.

Research design, approach and method: A qualitative research was carried out in eight hotels that employ the strategy of the case study in the aforementioned countries.

Main findings: Currently, no policies for green management exist, although some hotels do engage in some environmentally-friendly practices. Some hotel managers do not implement green management initiatives to mitigate the environmental problems emanating from their hotel operations.

Practical and/or managerial implications: This indicates that a gap exists between managers' awareness of appropriate environmentally-friendly practices for hotels, implying a need for training and increased awareness of green management.

Contribution and/or value-add: The results could guide managers in the implementation of environmentally-friendly practices in an effort to mitigate environmental problems facing the present generation.

\section{Introduction}

Increased demand on energy supply, an increased burden on solid waste management and the pollution of water bodies, soil and air are among the high level of negative environmental effects in the hospitality sector of the tourism industry (Kasim 2006:4). Owing to these effects, substantial uncertainty exists regarding the long-term implications of such negative environmental impacts, in particular, those relating to global climate change (Rogerson \& Sims 2012:291). This increasingly calls for 'greening' of the hospitality sector and the creation of carbon-neutral accommodation at various destinations.

Accommodation (hotels and other lodging establishments) is one of the substantial areas of the hospitality sector (Ottenbacher, Harrington \& Parsa 2009:66). As an important component of the accommodation sector, hotel operations are characterised by a massive number of activities that collectively exert a significant impact on global resources (Kirk 1995:3). The considerable environmental effects of hotels contribute to problems, many of which are international in scope, with the major one being climate change (Andrea 2007:1916; Bohdanowicz, Zientara \& Novotna 2011:801). Hotel operations produce emissions of greenhouse gases, which are released into the air, in particular, $\mathrm{CO}_{2}$ and chlorofluorocarbons (Kirk 1995:5; Verginis \& Wood 1999:133). Moreover, it has been shown that of all commercial buildings, hotels exert the greatest negative influence on the environment. According to estimations, an average hotel releases between $160 \mathrm{~kg}$ and $200 \mathrm{~kg}$ of $\mathrm{CO}_{2}$ per square metre of room floor area per year and the water consumption per guest per night is between 170 and 440 litres in the average five-star hotel. On average, hotels produce $1 \mathrm{~kg}$ of waste per guest per night (Han, Hsu \& Sheu 2010:325). 
Furthermore, a growing concern to establish a 'green' hotel in the view of customers is evident (Chan \& Ho 2006:301), as they are experiencing an increased awareness of environmental damage and excessive consumption of goods, energy and water (Han et al. 2010:325). With the negative impacts that hotels exert on the environment, greater pressure is placed on governments and role players in tourism to reinforce eco-friendlier enterprises and green consumption in hotels (Moreo 2008:1). This compels hotels to demonstrate responsible behaviour to become 'eco-friendly hotels' or 'green hotels', which refers to accommodation establishments that have made a commitment to implementing or following various ecologically-sound practices, such as saving water and energy as well as reducing solid waste (Manaktola \& Jauhari 2007:365).

Limited information is available regarding green management efforts in the hotel sectors in Zimbabwe and South Africa, yet the number and range of impacts that hotels exert on the environment suggest an urgent need for action to mitigate these effects (Dondo, Bhunu \& Rivett 2002:198; Rogerson \& Sims 2012:401; Spenceley 2005:7; Van der Merwe \& Wocke 2007:30). According to Spenceley (2005:7), at present there is a fragmented development, formulation and implementation of policies, initiatives and guidelines for green management in hotels in these two countries, which is a cause for concern. Hence, policies and guidelines on green management need to be put in place and those that have been formulated need to be implemented in order to meet the tourist demand for more environmentally-friendly accommodation.

In Zimbabwe and South Africa, the hospitality sector is facing an increasing burden regarding solid waste (Nhapi \& Gijzen 2005:133), pollution of water bodies (Feresu \& Van Sickle 2008:398) and excessive use of energy and water (Lee et al. 2010:901). Against this backdrop, this study examines issues relating to environmentally-friendly practices of hotels in these two developing countries, a topic that has received scant interest in the sub-Saharan Africa, according to Rogerson and Sims (2012:392). This study is of great importance as there is much pressure on hotels to become green and the hotels in Zimbabwe and South Africa cannot continue to be oblivious to managing green practices. Accordingly, there was a need to address the following key questions:

- Are there any green management practices in hotels?

- Are there any green management policies in hotels?

- What are the reasons for implementing green management initiatives in hotels?

\section{Literature review}

\section{Tourism environmental impacts}

The link between tourism and the environment has been emphasised as one that has been assuming greater significance with the rise of the sustainability debate (Page 2009:492). Since the Rio Earth Summit in 1992, the environmental and social impacts of the tourism industry have emerged at the forefront of global discussion (Graci 2009:39). Deteriorating conditions of the world's natural resources inspired an agreement among world leaders that sustainable development be the central target of governments and business organisations.

Literature reveals that in many parts of the world, accommodation-based sewage and waste materials are dumped directly into lakes, rivers and seas without any kind of processing beforehand, thus creating health hazards and an aesthetically unpleasant environment (Timothy \& Teye 2009:82). As a component of tourism, the hospitality sector has played a decisive role in ecological deterioration, although its impacts have not been as profound as those of automobiles, airlines and cruise ships (Timothy \& Teye 2009:81). However, an increased burden of solid waste is an additional key environmental impact of hotel operations (Taylor et al. 1994:173). Therefore, it would be characteristic of good ecological stewardship for hotels to take action in this regard in the quest to green the physical environment (Timothy \& Teye 2009:81).

Hotels, as the primary accommodation, play a major role in hospitality and they exert a significant economical, ecological and social impact on the environment (Taylor et al. 1994:169). Because hotels exert a negative environmental impact, it is imperative that the management of hotels take action to mitigate their impact on the environment. A considerable number of studies have focused on environmental management measures in hotels in order to efficiently deal with environmental issues arising from their operations (Alvarez, Burgos \& Cespedes 2001:458; Bansal 2005:209; Bohdanowicz et al. 2011:798; Hsieh 2012:98; Timothy \& Teye 2009:84). In these studies, management measures were developed to efficiently deal with environmental issues that hotels can use, for instance, recycling of waste and supplying clean air as well as energy and water conservation, environmental health and environmental education for staff and customers (Hsieh 2012:98). A study carried out by Du Plessis, Van der Merwe and Saayman (2012) suggests that accommodation units be supplied with environmentally friendly products such as biodegradable soaps and detergents. They also suggest the use of paperless communication and billing systems where possible and the provision of maps or any other information on recycled paper where aesthetically acceptable. These green management practices are meant to attract business from markets that favour green practices (Manaktola \& Jauhari 2007:364).

\section{Greening trends in hotels}

Within the hotel sector, the areas of concern for the environment include pollution through solid and liquid waste, high energy consumption and the increasing release of greenhouse gases that cause changes in the atmosphere. Consequently, practices such as recycling of waste, waste management, supplying clean air, energy and water conservation, environmental health, adopting a purchasing 
policy and environmental education are being considered in various hotels in mitigation of the negative impacts on the environment (Mensah 2006:415). Quite a number of best practices are undertaken in the hotel sector in this regard. This will render the sector more sustainable and environmentally friendly. Given that $85 \%$ of leisure travellers consider themselves environmentally conscious, that is, 'green' consumers (Miller, Mayer \& Baloglu 2012:395), some hotels have embraced the principles of sustainable development to mirror customer concerns and have thus attempted to minimise the energy consumed during the customers' stay through the introduction of minor measures such as re-using linen and towels (Page 2009:287). Major steps have also been taken by hotels, which have conducted environmental audits to assess the environmental costs of their activities in relation to energy consumption, transport, waste, purchasing, health and the local environment (Page 2009:288). Environmental sustainability is one of the major aspects to be considered regarding general sustainability (Jeter 2009:9; Page 2009:287).

Demands from governments or regulators require hotels to implement green practices (Kim \& Choi 2013:159). Green practices are ways to use products and methods that would not negatively impact on the environment through pollution or by the depletion of natural resources (Smith \& Perks 2010:3). These green practices include sustainable management of water, energy conservation, solid waste management, ensuring air quality, environmental purchasing, community awareness and maintenance of permits (see Table 1).

The aforementioned practices are practised by some highly branded green hotels in certain parts of the world. Such practices could possibly be used in Zimbabwe and South Africa to mitigate the environmental impacts of hotels.

\section{The current situation in Zimbabwe and South Africa}

A study conducted in Zimbabwe revealed that there is no existing legislation for environmentally-friendly initiatives to be mandatory in hotels (Maphosa 1997:1). Concern is also raised regarding waste dumping sites in Zimbabwe as some of the waste is discharged into aquatic environments in contradiction with the prescribed water pollution control standards (EMA:CAP 2002:72). A study undertaken on an approach to sustainable wastewater management based on pollution prevention and minimisation, treatment and reuse raised concerns about water loss both at the treatment plant and in the distribution line (20\%) (Nhapi \& Gijzen 2005:137). Thus, the study revealed a scant awareness regarding the management of environmental resources.

In South Africa, a number of surveys were carried out in an attempt to establish the level of participation of tourism organisations in responsible tourism (Dondo et al. 2002:198; Rogerson \& Sims 2012:398; Spenceley 2005:3; Van der

TABLE 1: Green practices in hotels.

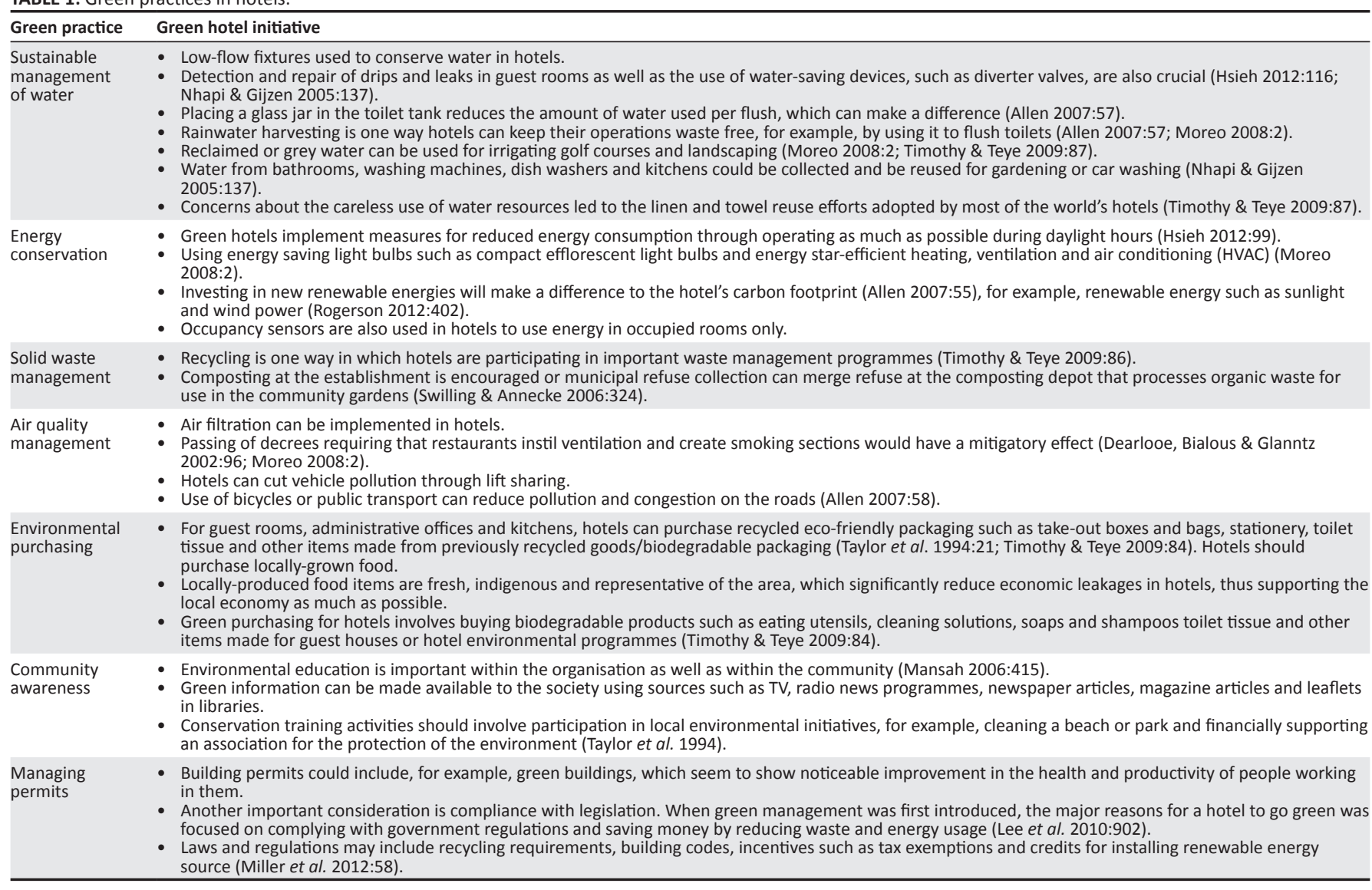

Source: Authors' own work 
Merwe \& Wocke 2007:30). A study conducted on responsible tourism practices in the South African hotel sector revealed that a high percentage of hotels in South Africa does not participate in responsible tourism, mainly because there are no legal or industry regulations requiring them to do so (Van der Merwe \& Wocke 2007:7).

\section{Method of research}

The method used in this research followed a case study approach. In this study, multiple case studies were used to collect data from eight hotels. In order to reach the goal of the study, a qualitative research approach was employed.

\section{Participants}

All the participants in this study shared a common feature in that they were hotel managers in three- to five-star-graded hotels in South Africa and Zimbabwe. These hotels are spread throughout the countries in both urban and rural areas. Purposive sampling was employed to determine the sample. The sample that was chosen comprised four hotel managers in Zimbabwe and four hotel managers in South Africa. They were general managers who possess knowledge of all the policies and environmentally friendly practices within their hotels.

\section{Development of the interview schedule}

An interview schedule was developed according to variables developed in previous case studies pertaining to green management in hotels. Examples of these case studies can be found in the research conducted by Hsu and Sheu (2009:325), Moreo (2008:1), Robbins (2001:23) and Taylor et al. (1994:128). The interview schedule consisted of research constructs from previous frameworks and comprised two sections with questions that were largely open ended.

\section{Data collection}

Semi-structured interviews were used to collect data for this study from a sample comprising managers in star-graded hotels in Zimbabwe and South Africa. A digital voice recorder was employed as the main tool for recording the interviews while field notes were taken.

\section{Data analysis}

Themes were identified from the transcribed data. In this study, the researcher took the following steps formulated by Cresswell (2009) in order to analyse the data: Step 1: Organise and prepare data for analysis; Step 2: Read through all data, gain a general sense of information and reflect on the meaning; Step 3: Conduct an analysis based on a specific theoretical approach and method (this often involves coding or organising related segments of data into categories); Step 4: Generate a description of the setting or people and identify themes from the coding. Search for connections between the themes; Step 5: Represent data within a research report; and Step 6: Interpret the larger meaning of the data.

\section{Ethical considerations}

Issues of confidentiality were taken into consideration and interviewees were assured that the data would be kept confidential and that the names of the interviewees would not be mentioned. Ethical approval was obtained.

\section{Results}

The following section outlines the responses by the participants regarding environmentally friendly practices in hotels in Zimbabwe and South Africa. Hotel cases 1-4 represent the Zimbabwean respondents, while cases 5-8 represent the South African respondents. The trustworthiness of the data was enhanced by the fact that all managers are well educated and had worked in establishments that had been in operation for more than 10 years.

\section{Availability of green management policy}

The first question sought to establish the availability of green management policies in the hotels. Cases 1 and 3 have no (written) policy on green management, although case 1 does have a waste management policy. This situation is different from that of case 2, who said that the hotel does have a green management policy available. Case 4, on the other hand, argues that it has a green management policy, but is not willing to share what this policy entails. With respect to Zimbabwe, it is observed that the hotels have no articulate written policies.

The South African cases clearly indicate that these hotels concur, while the data of their Zimbabwean counterparts are contradictory in that they do not have green management policies. Yet, the latter hotels do implement some kind of green initiatives.

In case 5, the hotel has no policy that prescribes how green management should be carried out. Nonetheless, the initiatives within the hotel stress the need to save resources and 'go green'. Although case 6 said that they do not have any policy, they practise switching off lights, especially in those rooms without any guests. The hotel uses natural light during the day. This is similar to case 1 and case 5, which do not have green management policies, but do implement some green initiatives. Case 7 said that it has a green management policy. The policy prescribes that if a person visits the hotel several times, a tree is planted in honour of that person and the person's name is placed on it. While case 8 has no written green management policy, the hotel is in the process of developing one. Meanwhile, the hotel has implemented a water-saving project.

The general trend in all eight hotels is that even where there is no green management policy, some green management initiatives have been implemented. The majority of hotels, however, have no green management policies. This implies that the implementation of green initiatives is being carried out in a haphazard manner, without the guidance of a policy. Having a policy is important as policies reflect an interest in 
the amelioration of environmental impacts in a hotel (Miller et al. 2012:51). Knowledge of such policies is probably shallow or perhaps there are no green management policies at all in the hotels. The unavailability of green management policies in most of the hotels suggests that these hotels lack knowledge about the importance of green management policy. Consequently, the hotels do not have anywhere from which to draw guidance and therefore there are no set standards for green management initiatives. Quality tends to decline where there is no green management policy as a lack of organisational learning with regards to green issues leads to lack of growth and eventually business is affected. Hsieh (2012:105) argues that a green management policy is a top management's declaration of its commitment to the environment.

It is recommended that hotel managers establish green management policies within their hotels. Such policies provide rules and guidelines as well as prescribe what should be done to mitigate the environmental impacts, which emanate from the operations of a hotel.

\section{Green management initiatives}

The second question intended to establish whether green management initiatives exist in the hotels. The initiative of case 1 is to switch off electricity whenever possible. It also uses solar energy and recycles materials such as plastics. Case 2 practises load shedding. It has replaced incandescent lamps with energy-saving bulbs. The green management initiatives of case 3 involve the use of key cards and prescribe that clients switch off all lights when leaving the room. However, with regard to e-mails, the hotel does not have a print policy to promote a paperless environment. Case 4 uses boilers with timing switches. It also uses thermostat technology for fryers and energy savers. Case 5 encourages guests to use their towels twice before placing them into the laundry. The initiatives of case 6 include switching off lights in the restaurant and kitchen during the day when there are no guests. It also uses borehole water, which is locally available. Case 7 engages in green initiatives such as the reuse of soap bottles, which involves refilling bulk containers with soap with the principal aim of reducing waste. The hotel also applies solid waste separation for which dedicated bins are allocated for glass, plastic and food scraps. In addition, the hotel uses vegetables grown in its own garden. In case 8, water saving and reuse of wastewater are practised.

All the initiatives point to the importance of saving, which ranges from saving energy, particularly electricity, to saving water and resources such as soap and similar materials. Energy saving by means of load shedding and the use of energy saving bulbs, use of key cards (which switch off all lights on leaving the room) and the use of thermostat technology for fryers are some of the green management initiatives that were revealed in this study. Other green initiatives include the use of boilers (which have timing systems) and switching off lights in the restaurant and kitchen during the day. In the literature, for example,
Rogerson and Sims (2012:402) encourage the use of renewable energy such as sunlight and wind energy in order to save electricity. Another finding was that of having a no-print policy to promote a paperless environment, for example, with respect to e-mails, as encouraged in literature by scholars such as Allen (2007:57), who argues for a reduction of waste and keeping a hotel waste efficient.

The finding that guests should use their towels twice before they are laundered, as revealed by this study, is consistent with existing literature. For example, Timothy and Teye (2009:87) have argued against the careless use of water resources. Also, current green hotel initiatives aim at reduced water consumption and the reuse of soap bottles (Rogerson \& Sims 2012:402). However, green initiatives such as using soap and shampoo dispensers to reduce waste may give an impression of compromised service quality to customers and may be contrary to guest expectations (Kim \& Choi 2013:160).

It is recommended that hotels implement and monitor the progress of the green initiatives in their establishments. The initiatives to be implemented may include any or some of the following:

- Water - Water may be saved by flushing toilets using a flushing system fed from rainwater harvesting. In addition, hotels can use low-flow shower heads and taps to reduce waste.

- Energy - Occupancy sensors can be used in hotels so as to use energy in occupied rooms only. Also, hotels can use renewable energies such as solar power and wind energy.

- Reuse of linen - Reuse of linens and towels save water, detergent and energy which reduces the release of greenhouse gases. Water saving information cards should be placed in rooms for guests to read.

- Solid waste - Recycling is one way by which hotels can begin to participate in waste management. Composting at the establishment is also encouraged.

- Air quality - Air filtration can be installed in hotels. In addition, the creation of smoking sections for guests to avoid involuntary exposure to second-hand smoke can also be helpful.

- Installation of green roofs improves air quality, which includes the use of recycled material in the growing medium.

- Environmental purchasing - Hotels should avoid procuring plastic-based packaging, which contributes to high levels of pollution and should rather use paper bags made from recycled products.

Initiatives that are implemented need to be monitored. Monitoring is the systematic and routine collection of information regarding an initiative, which is subsequently used for evaluation of the initiatives.

It is recommended that hoteliers engage in the education of customers regarding environmental impacts, which emanate from the hotel's activities and their consumption behaviour. In addition, customers need to be educated regarding the 
environmentally-friendly consumption of goods and services during their stay in the hotel. Furthermore, customers need to be educated on eco-taxes so that they may appreciate that through payment of such taxes, they are making a positive contribution towards the protection of the environment.

There is a need for hoteliers to send their employees to attend courses developed by green initiative agencies, colleges and universities with respect to the concept of green management and environmentally-friendly practices. This would assist hoteliers to understand how their businesses contribute to the environmental problems facing our present generation. They will also be in a position to appreciate that they have a role to play in mitigating the environmental impacts through environmentally-friendly initiatives.

\section{Reasons for implementing green management initiatives}

The third question sought to identify the reasons for implementing green management initiatives in the hotels that were studied. Case 1 argues that the reason for the implementation of green management initiatives is to save resources and therefore reduce costs. Case 2 also echoes the notion of cost saving. Also, the hotel argues that its main idea is the prevention of damage to the environment, hence ensuring a sustainable environment for future use. In case 3, the purpose of green management initiatives is to reduce costs and to encourage adherence to environmental friendliness. Along similar lines, case 4 stresses cost reduction. Case 5 implements green management initiatives with the main aim to save resources, while case 6 also emphasises cost saving. Case 7 is motivated by green management initiatives for marketing purposes, thus ensuring a competitive advantage and satisfying the needs of its clients. Case 8 says that it has a concern for the environment, besides working towards obtaining a four-star rating. This is pertinent to the ratings so that it is evident on the scorecard that the hotel is engaged in green initiatives. The principal theme that emerged is cost saving.

The findings of the study are therefore that green management initiatives are implemented in order to save resources that would result in a reduction in operational costs, despite the absence of policies that could serve as guidelines. Saving resources is achieved through the prevention of environmental damage and ensuring that the environment is sustainable for future generations. The argument for sustainability of the environment is an important reason for implementing green management because sustainability has become a new order and many scholars and practitioners now argue that without a significant change towards a more sustainable approach to development, severe damage to cultural and natural resources will accelerate the world over (Okeiyi et al. 2005:39).

The purpose of green management initiatives is to ensure that the hotel is environmentally friendly. This finding is consistent with literature as Bohdanowicz et al. (2011:297) argue that environmentally-responsible hotel companies seek to green all their operations, thereby minimising their environmental impacts through the sustainable management of resources such as water, energy, air and land. Chen and Chen (2012:211) maintain that if the hotel industry can put the idea of green management into practice, not only will it benefit environmental and ecological protection, but it would also reduce the cost of the hotel operations.

The study has also established that green management initiatives are sometimes implemented for marketing purposes. Kim, Palakuthi and Hancer (2012:196) argue for the ecologically-conscious marketplace. Thus, hotels that mitigate the negative impacts on the environment emphasise this at the operations level of the business (Table 2). As noted in literature, food preparation in hotels makes the biggest contribution to the carbon footprint, accounting for $70 \%$ of the ecological footprint on average across the board in star-rated hotels, while accommodation accounts for $25 \%$ of the carbon footprint in star-rated hotels (Chen \& Hsieh 2011:7).

\section{Conclusion}

This research study determined the environmentally friendly practices adopted in 3- to 5-star-graded hotels in Zimbabwe and South Africa. This was the first time that a study of this nature was carried out on green practices in hotels. Hotels play a major role in accommodating the travelling public. However, in Zimbabwe and South Africa, the hospitality sector is facing an increasing burden of solid waste as well as excessive use of energy and water. Against this background, this study was conducted to examine issues relating to environmentally-friendly practices of hotels in these two developing countries. It has become imperative that hotels take action to mitigate their negative impact on the environment. Concerning the availability of green management policy, the study revealed that while the hotels that participated in the study generally have no green management policies, they have implemented some green initiatives. Green management initiatives implemented in hotels range from energy saving, use of solar energy, maintaining a paperless environment through a no-print policy, saving water by using towels more than once before laundering, reuse of soap bottles and waste management. Some green management initiatives have been implemented in all the hotels in both Zimbabwe and South Africa. The reasons for implementing green management initiatives include saving resources and reducing costs as well as protecting the environment so that it becomes sustainable. This implies that the implementation of such initiatives has been haphazard rather than systematic. The study has also revealed that green management has been adopted by some hotels for marketing reasons in order to retain customers and to gain a competitive advantage. It is recommended, as a result of this study, that hotels develop green management policies to guide the implementation of environmentallyfriendly practices. 
TABLE 2: Summary of green management initiatives in hotel cases 1-8.

\begin{tabular}{|c|c|c|c|}
\hline Case & Availability of green management policy & $\begin{array}{l}\text { Green management initiatives implemented by the } \\
\text { hotel }\end{array}$ & $\begin{array}{l}\text { Reasons for implementing green management } \\
\text { initiatives }\end{array}$ \\
\hline 1 & $\begin{array}{l}\text { The hotel has no policy on green management. } \\
\text { There is a waste management policy. }\end{array}$ & $\begin{array}{l}\text { The hotel initiatives include switching off switches and } \\
\text { the use of solar energy as well as recycling of plastics. }\end{array}$ & $\begin{array}{l}\text { Purpose of green management initiatives is done to } \\
\text { save resources. } \\
\text { Cost saving in the short- to long run. }\end{array}$ \\
\hline 2 & $\begin{array}{l}\text { The hotel has a green management policy. } \\
\text { The policy encourages guests to conserve water. } \\
\text { There are air conditioning units that operate with a card. }\end{array}$ & $\begin{array}{l}\text { The hotel initiatives: } \\
\text { Load shedding } \\
\text { Changed from incandescent lamps to energy saving } \\
\text { bulbs. }\end{array}$ & $\begin{array}{l}\text { For cost saving: } \\
\text { To avoid damaging the environment. } \\
\text { To make the environment sustainable for future use. }\end{array}$ \\
\hline 3 & The hotel has no policy on green management. & $\begin{array}{l}\text { The hotel uses key cards which switch off all lights } \\
\text { on leaving the room. } \\
\text { No-print policy for e-mails. }\end{array}$ & $\begin{array}{l}\text { To reduce costs. } \\
\text { To be environmentally friendly. } \\
\text { The subtheme is cost saving. }\end{array}$ \\
\hline 4 & $\begin{array}{l}\text { The hotel has a green management policy, but the } \\
\text { participant was not ready to share what it says. }\end{array}$ & $\begin{array}{l}\text { The hotel has boilers that have timing systems. } \\
\text { The hotel uses thermostat technology for fryers. } \\
\text { The hotel uses energy savers. }\end{array}$ & For cost reduction. \\
\hline 5 & $\begin{array}{l}\text { The hotel has no green management policy prescribing } \\
\text { what should be done but there are some initiatives to save } \\
\text { and go green. }\end{array}$ & $\begin{array}{l}\text { The hotel encourages guests to use their towels } \\
\text { twice before laundry. }\end{array}$ & $\begin{array}{l}\text { The hotel implements green management initiatives } \\
\text { with the main reason of saving. }\end{array}$ \\
\hline 6 & $\begin{array}{l}\text { The hotel has no policy, but they have an initiative to switch } \\
\text { off lights in rooms where there are no guests and use } \\
\text { natural light during the day. }\end{array}$ & $\begin{array}{l}\text { The hotel initiatives include switching off lights in } \\
\text { restaurant and kitchen during the day when there } \\
\text { are no guests. } \\
\text { The hotel uses borehole water. }\end{array}$ & $\begin{array}{l}\text { Cost saving is the main reason why the hotel } \\
\text { implements green management initiatives. }\end{array}$ \\
\hline 7 & $\begin{array}{l}\text { The hotel has a green management policy which says if a } \\
\text { person revisits the hotel several times, a tree is planted } \\
\text { in honour of that person and has the person's name placed } \\
\text { on it. }\end{array}$ & $\begin{array}{l}\text { The hotel reuses soap bottles. } \\
\text { There are bins allocated for glass, plastic and food } \\
\text { scraps. } \\
\text { The hotel uses vegetables which they grow in the } \\
\text { garden. }\end{array}$ & $\begin{array}{l}\text { The reason hotel implements green management } \\
\text { initiatives for marketing purposes so as to have a } \\
\text { competitive advantage and keep clients. }\end{array}$ \\
\hline 8 & $\begin{array}{l}\text { The hotel has no written green management policy yet but } \\
\text { is in the process of working on one. } \\
\text { The hotel has, however, implemented a water saving project. }\end{array}$ & $\begin{array}{l}\text { The hotel initiates water saving and they make use of } \\
\text { waste water. }\end{array}$ & $\begin{array}{l}\text { The hotel implements green initiatives because of } \\
\text { concern for the environment. } \\
\text { In addition, the hotel is working on obtaining a } \\
\text { four-star rating and it is pertinent regarding the } \\
\text { ratings that the hotel is seen to be doing something } \\
\text { from a green perspective on the score card. }\end{array}$ \\
\hline
\end{tabular}

Source: Authors' own compilation from Interviewers (2014)

\section{Acknowledgements}

The authors would like to acknowledge outside reviewers of their drafts and the National Research Fund for funding that supported the research.

\section{Competing interests}

The authors declare that they have no financial or personal relationship(s) that may have inappropriately influenced them in writing this article.

\section{Author contributions:}

This research formed part of the PhD study conducted by M.M., which was supervised by E.d.P. Both M.S. and M.K. acted as co-supervisors.

\section{References}

Allen, Y., 2007, Innovation pushes Edmonton to the leading edge of waste management, viewed 19 October 2015, from https://www.fcm.ca/Documents/ presentations $/ 2007 / \mathrm{mission} / \mathrm{Innovation} \_p u s h e s$ Edmonton_to_the_leading_ edge_of_waste_management_EN.pdf

Alvarez, G.M.J., Burgos, J.J. \& Cespedes, L.J.J., 2001, 'An analysis, of environmental management, organisational context and performance of Spanish hotels', The International Journal of Management Science 29(1), 457-471. http://dx.doi. org/10.1016/S0305-0483(01)00033-0

Andrea, M.O., 2007, 'Atmospheric aerosols versus greenhouse gases in the twentyfirst century philosophical transactions', Mathematical, Physical and Engineering Sciences 365(1865), 1915-1923.

Bansal, P., 2005, 'Evolving sustainability: A longitudinal study of corporate sustainable development', Strategic Management Journal 26(3), 197-218. http://dx.doi. org/10.1002/smj.441

Bohdanowicz, P., Zientara, P. \& Novatna, E., 2011, 'International hotel chains and environmental protection: An analysis of Hilton's we care programme (Europe, 2006-2008)', Journal of Sustainable Tourism 19(7), 797-816. http://dx.doi.org/ 10.1080/09669582.2010.549566

Chan, W.W. \& Ho, K., 2006, 'Hotels Environmental management systems (ISO 14001): Creative financing strategy', International Journal of Contemporary Hospitality Management 18(4), 302-316. http://dx.doi.org/10.1108/09596110610665311
Chen, H. \& Hsieh, T., 2011, 'An environmental performance assessment of the hote industry using an ecological footprint', Journal of Hospitality Management and Tourism 2(1), 1-11.

Chen, V.C. \& Chen Y.T., 2012, 'The advantages of green management for hotel competitiveness of green management for hotel competitiveness in Taiwan: In the viewpoint of senior hotel managers', Journal of Management and Sustainability 2(2), 211-218. http://dx.doi.org/10.5539/jms.v2n2p211

Cresswell, J.W., 2009, Research design: Qualitative, quantitative, and mixed methods, approach, 3rd edn., Sage Publications, London.

Dearlooe, J.V., Bialous, S.A. \& Glanntz, S.A., 2002, 'Tobacco industry manipulation of the hospitality industry to maintain smoking in public places', Tobacco Control 11(2), 94-104. http://dx.doi.org/10.1136/tc.11.2.94

Dondo, C.H., Bhunu, S.T. \& Rivett, U., 2002, 'GIS In Tourism - A Zimbabwean perspective', The International Archives of the Photogrammetry, Remote Sensing and Spatia Information Sciences 34(6), 197-200. http://dx.doi.org/10.1.1.398.3525

Du Plessis, L., Van der Merwe, P. \& Saayman, M., 2012, 'Tourists perceptions on whether South African national parks are environmentally friendly', Acto Academia 45(1), 187-208.

Environmental Management Agency (EMA) CAP 20, viewed 6 December 2014, from http://www.panda org

Feresu, S.B. \& Van Sickle, J., 2008, 'Coliforms as a measure of sewage contamination of the River Zambezi', Journal of Applied Microbiology 68(4), 397-403.

Graci, S., 2009, 'Examining the factors that impede sustainability in China's tourism accommodation industry: A case study of Sanya, Hainan, China', Journal of Hospitality Marketing \& Management 19(1), 38-55. http://dx.doi.org/10.1080/ 19368620903327683

Han, H., Hsu, J. \& Sheu, C., 2010, 'Application of the theory of planned behavior to green hotel choice: Testing the effect of environmental friendly activities', Tourism Management 31(3), 325-334. http://dx.doi.org/10.1016/j.tourman 2009.03.013

Hsieh, Y., 2012, 'Hotel companies' environmental policies \& practices: A content analysis of web pages', International Journal of Contemporary Hospitality Management 24(1), 97-121. http://dx.doi.org/10.1108/095961112

Hsu, J. \& Sheu, C., 2009, 'Application of the theory of planned behaviour to green hotel choice: Testing, the effect of environmental friendly activities', Tourism Management 31(3), 345-334.

Jeter, P.M., 2009, 'Green inside and out: Case study of green events in large public assembly', Master's thesis, School of Hotel, Restaurant and Tourism Management, University of South Carolina.

Kasim, A., 2006, 'The need for business environmental and social responsibility in tourism industry', International Journal of Hospitality and Tourism Administration 7(1), 1-22. http://dx.doi.org/10.1300/J149v07n01 01

Kim, S.H. \& Choi, Y., 2013, 'Hotel employees' perception of green practices', International Journal of Hospitality \& Tourism administration 14(2), 157-178. http://dx.doi.org/10.1080/15256480.2013.782220

Kim, Y.J., Palakuthi, R. \& Hancer, M., 2012, 'The environmentally friendly programmes in hotels and customers intention to stay: An online survey approach', International 
Journal of Hospitality \& Tourism Administration 13(3), 195-124. http://dx.doi. org/10.1080/15256480.2012.698169

Kirk, D., 1995, 'Environmental management in hotels', International Journal of Contemporary Hospitality Management 7(6), 3-8. http://dx.doi.org/10.1108/ 09596119510095325

Lee, J.S., Hsu, L.T., Han, H. \& Kim, Y., 2010, 'Understanding how consumers view green hotels: How a hotel's green image can influence behavioural intentions', Journal of Sustainable Tourism 18(7), 901-914. http://dx.doi.org/10.1080/09669581003777747

Manaktola, K. \& Jauhari, V., 2007, 'Exploring consumer attitude and behaviour towards green practices in the lodging industry in India', International Journal of Contemporary Hospitality Management 19(5), 364-377. http://dx.doi.org/ 10.1108/09596110710757534

Maphosa, F., 1997, 'Corporate social responsibility in Zimbabwe: A content analysis of mission statements and annual reports', Zambezia XXIV(ii), 180-193.

Mensah, I., 2006, 'Environmental management practices among hotels in greater Accra region', International Journal of Hospitality Management 25(3), 414-431. http://dx.doi.org/10.1016/j.ijhm.2005.02.003

Miller, M., Mayer, K.J. \& Baloglu, S., 2012, 'Importance of green hotel attributes to business and leisure travellers', Journal of Hospitality Marketing \& Management 21(4), 395-413. http://dx.doi.org/10.1080/19368623.2012.624294

Moreo, A., 2008, 'Green consumption in hotel industry an examination of consumer attitudes', Master's thesis, University of Delaware, Newark, DE.

Nhapi, I. \& Gijzen, H.J., 2005, 'A 3 Step Strategic approach to sustainable wastewater management', Water SA 31(1), 133-140. http://dx.doi.org/10.4314/wsa.v31i1.5130

Okeiyi, S.I., Okrah, A.M., Okeiyi, E.C. \& Bryant, B.A., 2005, 'Operator attitude toward sustainable tourism development concept in Ghana', Journal of Business 6(1) 33-52. http://dx.doi.org/10.1300/J156v06n01_03
Ottenbacher, M., Harrington, R. \& Parsa, H., 2009, 'Defining the hospitality discipline: A discussion of pedagogical \& research implications', Journal of
Hospitality \& Tourism Research 33(3), 263-283. http://dx.doi.org/10.1177/ Hospitality \& Tourism

Page, J.P., 2009, Tourism management: Managing for change, Elsevier Ltd., London.

Robbins, T. 2001, Greening the corporation: Management strategy and the environmental challenge, Earthscan Publications Ltd, London.

Rogerson, J.M. \& Sims, S.R., 2012, 'The greening of urban hotels in South Africa: Evidence from Gauteng', Urban Forum 23(3), 391-407. http://dx.doi.org/10.1007/ s12132-012-9160-2

Spenceley, A. 2005. Tourism certification initiatives in Africa. The International Ecotourism Society (TIES), Washington, DC.

Smith, E.E. \& Perks, S., 2010, 'A perceptual study of the impact of green practice implementation on business functions', Southern Africa Business Review 3(14), $1-29$.

Swilling, M. \& Annecke E., 2006, 'Building sustainable neighbours in South Africa: Learning from the Lynedoch case', Environment and Urbanization 18(2), 315-332. http://dx.doi.org/10.1177/0956247806069606

Taylor, B., Hutchison, C., Pollack, S. \& Tapper, R., 1994, The environmental management handbook, Pitman, London.

Timothy, D.J. \& Teye, V.B., 2009, Tourism and the lodging sector, Elsevier, Oxford.

Van der Merwe, M. \& Wocke, A., 2007, 'An investigation into responsible tourism practices in South African hotel industry', South African Journal of Business Management 38(1), 1-17.

Verginis, C.S. \& Wood, R.C., 1999, Accommodation management: Perspectives for the international hotel industry, Thomson Business Press, London. 